DOI 10.31558/2519-2949.2018.2.21

УДК 327.8 (321.01)

\author{
Літвін Л. А., Східноукраӥнський національний університет \\ імені Володимира Даля
}

\title{
СУЧАСНІ КОНЦЕПЦІЇ НАЦІОНАЛЬНИХ ІНТЕРЕСІВ У КОНТЕКСТІ ЗОВНІШНЬОЇ ПОЛІТИКИ ДЕРЖАВ
}

Метою роботи є аналіз сучасних концепцій національних інтересів у контексті зовнішньої політики держав. Визначено, що саме начіональні інтереси детермінують стратегію й тактику зовнішньої політики держави, характер міжнародних відносин і особливості внутрішньої політики. Зазначено, щьо практичній реалізачї національних інтересів повинне передувати теоретичне обтрунтування різних конщепџій. Більше того, вивчення й аналіз існуючих конщепцій національних інтересів є необхідною умовою створення нової власної конщепџії, щуо відповідатиме ефективному розвитку держави, міжнародним і внутрішнім умовам.

Визначено особливості таких концепиій як «стратегія швидкого реагування», концепиія «взаємно гарантованого знищення», «східна політика», «залізна завіса», доктрина «масованої відплати», програма «нових кордонів», політика «блискучої ізоляції», доктрина «залякування», «Холодна війна», «гібридна війна». Означені історичний контекст та характеристика подій щодо реалізачії концепцій нащіональних інтересів державами світу. Визначені особливості міжнародних відносин у ці періоди. Звертається увага на наукову дискусію щзодо сучасного поняття «гібридна війна», названі основні компоненти «гібридної війни». Зазначено, що «політика нових кордонів» поєднує в собі всі елементи, необхідні для гармонійного розвитку держави.

Уточнено, що проаналізовані конщепиї демонструють силовий аспект, який домінує в теорії начіональних інтересів і в XX, і в XXI століттях. Зазначено, що й зараз переважає реалістичний підхід у політиці, а XXI століття закономірно демонструє перевагу інформачійних технологій у захисті, реалізації та демонстрачії начіональних інтересів.

Також уточнено, щзо тематика роботи торкається дискусійної проблеми, тому щьо проаналізовані концепції не всі дослідники вважають саме концепціями національних інтересів, відносять їх виключно до стратегій зовнішньої політики окремих держав. Зазначено, що концепиію національних інтересів розглядаємо як систему можливої реалізаиії національних інтересів конкретної держави в певний проміжок часу.

Ключові слова: національні інтереси, зовнішня політика, держава, стратегія.

Однією з основних категорій у сучасній політичній науці й дійсності є категорія національних інтересів. Саме національні інтереси визначають стратегію й тактику зовнішньої політики держави, характер міжнародних відносин і особливості внутрішньої політики. Практичній реалізації національних інтересів повинне передувати теоретичне обгрунтування різних концепцій. Більше того, вивчення й аналіз існуючих концепцій національних інтересів $\epsilon$ необхідною умовою створення нової власної концепції, що відповідатиме ефективному розвитку держави, міжнародним i внутрішнім умовам. У цьому полягає актуальність даного дослідження.

Метою роботи $\epsilon$ проаналізувати сучасні концепції національних інтересів у контексті зовнішньої політики держав.

У сучасній українській науці дослідження національних інтересів, зокрема, концепцій національних інтересів, національної безпеки, стратегій у зовнішній політиці є досить поширеними. Так, питання концепцій національних інтересів у своїх дослідженнях торкаються такі вчені як В. Манжола, Ю. Левенець, М. Требін, В. Константинов, М. Рижков, А. Субботін, Ю. Шаповал та інші. Дослідники розглядають національні інтереси в контексті міжнародних відносин, стратегій зовнішньої політики, інтеграційних питань. Українська дослідниця I. Вишневська розглядає, зокрема, стратегії захисту національних інтересів в американсько-китайських відносинах.

У той же час відкритим залишається питання системного аналізу концепцій національної безпеки в контексті зовнішньої політики держав.

Сучасні теоретичні розробки теорії національних інтересів датують 60 -ми роками XX ст. Серед них дослідники окреслюють такі концепції як «стратегія швидкого реагування», концепція «взаємно

(C) Літвін Л. А., 2018 
гарантованого знищення», «східна політика», «залізна завіса», доктрина «масованої відплати», програма «нових кордонів», політика «блискучої ізоляції», доктрина «залякування», «холодна війна», «гібридна війна» тощо [5].

Однією 3 концепцій національних інтересів в контексті зовнішньої політики дослідники називають стратегію «гнучкого реагування». Дана стратегія бере свій початок з середини 1961 р., коли був схвалений план СІОП-2, який і відобразив стратегію «гнучкого реагування». Цей план передбачав проведення п'яти взаємопов'язаних операцій зі знищення радянського ядерного комплексу, придушення системи ПВО, знищення органів та пунктів військового та державного управління, великих груп військ, а також нанесення ударів по містам. Загальна кількість цілей в плані склала шість тисяч. Разом із тим розробники плану врахували і можливість нанесення Радянським Союзом відповідей ядерного удару по території США. На початку 1961 р. була сформована комісія, в обов'язки якої входило розробити перспективні шляхи розвитку американських СЯС. В подальшому такі комісії створювались регулярно.

Восени 1962 р. Карибська криза змусила політиків усього світу поглянути на ядерну зброю 3 нової сторони. Вперше це явно грало роль стримуючого фактора. Нова стратегія в області розвитку оборонного, зокрема, ядерного, потенціалу передбачала різке нарощування кількості ядерних бойових блоків на балістичних ракетах при одночасному поліпшенні їх техніко-технічних характеристик, що повинно було забезпечити якісну військову перевагу. Вдосконалення стратегічних наступальних сил знайшло своє відображення в черговому плані - CIOП-4, прийнятому в 1971 р. Але під тиском громадськості керівництво США вимушено було пойти на переговори 3 питань ядерного роззброєння. Методи ведення таких переговорів регулювали поняття «ведення переговорів 3 позицій сили» - складова частина стратегії «реалістичного залякування». В 1972 р. було укладено Договір між США та СРСР про обмеження систем ПРО та Тимчасову угоду про деякі заходи щодо обмеження СНВ. Однак, нарощування стратегічного ядерного потенціалу політичних систем тривало [10, с. 292].

Наступною концепцією, яка корелюється 3 вищеозначеною, можна назвати концепцію «взаємно гарантованого знищення», яка пов'язана 3 теорією стримування - геополітичною теорією, розробленою американським дипломатом Дж. Кеннаном в 1940-х рр. Концепція «взаємно гарантованого знищення» - концепція, за якою світовий мир і порядок забезпечуються на основі неминучості тотальної відплати супротивника в разі нанесення по ньому першого ядерного удару. Ця теорія лягла в основу радянсько-американських відносин і світової політики як такої в другій половині XX століття. Основні положення теорії стримування продовжують зберігати свою актуальність і в XXI столітті, оскільки ядерна зброя досі грає значну роль у світовій політиці, $\mathrm{i}$ військові доктрини Росії і США багато в чому засновані на використанні іiі як «фактора стримування».

На думку критиків Кеннана, практика стримування призводить до гонки озброєнь i, як наслідок, до більшого ризику збройного конфлікту i загрози постійного бюджетного дефіциту через перефінансування військової промисловості. Крім того, теорія має на увазі прагматичний підхід і не враховує ідеологічних розбіжностей між сторонами [11, с. 524].

Наступною концепцією національних інтересів у контексті зовнішньої політики держав $є$ «нова східна політика». Ця стратегія була складовою зовнішньої політики ФРН з 1969 р. «Нова східна політика» мала на меті перегляд старих позицій і перехід до курсу на домовленості із СРСР та іншими соціалістичними сусідами, на визнання існуючих кордонів та повоєнних реалій. Про силове повернення втрачених територій мови не було. Але сам факт «невизнання» створював грунт для діяльності екстремістських організацій у ФРН. На Сході ж він використовувався 3 метою залякування загрозою західнонімецького реваншизму, що давало підстави для зміцнення радянського контролю в «соціалістичному таборі».

У руслі «нової східної політики» з грудня 1969 р. до серпня 1970 р. проходили переговори між ФРН і СРСР, які завершилися підписанням 7 серпня 1970 р. Московського договору, що став конкретною реалізацією нового курсу ФРН. Одне з найважливіших його положень зафіксувала ст. 3 , де було визнано, що «мир в Свропі можна зберегти тільки в тому випадку, якщо ніхто не зазіхатиме на сучасні кордони». Далі йшлося про відмову від територіальних претензій, від спроб вирішувати спори немирними засобами. Все це якнайкраще влаштовувало СРСР, бо означало примирення ФРН iз розколом Німеччини, з існуванням НДР. Принципове значення для справи розрядки міжнародної напруженості в Свропі мала «Домовленість про наміри сторін». Згідно 3 «Домовленістю», ФРН зобов’язалася поважати державну цілісність і самостійність НДР і укласти з НДР міждержавний договір. 
Так завершився важливий етап «нової східної політики» ФРН, який зміцнив європейську розрядку. Керівники країн Східної Європи сподівалися на подальше поліпшення відносин із ФРН, і ці сподівання не в останню чергу пов'язувалися з особистістю канцлера ФРН [4; 6; 11, с. 191].

Іншою концепцією національних інтересів у контексті зовнішньої політики держав $\epsilon$ «Доктрина масованої відплати», яка була основою військової політики США в період президентства Д. Ейзенхауера. Ця Доктрина передбачала збільшення стратегічної зброї для ядерного удару по містах країн соціалістичного блоку, i, зокрема, авіації з ядерною зброєю на борту. Більше того, доктрина масованої відплати припускала можливість нанесення першими раптового удару по СРСР і КНР ядерною зброєю. Основні положення доктрини масованої відплати були викладені 12 січня 1954 р. Дж. Ф. Даллесом [11, с. 372].

Однією з концепцій національної безпеки також називають «залізну завісу». «Залізна завіса»термін, який використовувався в літературі та засобах масової інформації країн Заходу для позначення символічного кордону держав із соціалістичними системами тоталітарного типу, що розглядалися як «закриті», ізольовані від решти світу. Вперше термін «залізна завіса» вжив російський письменник і філософ В. Розанов у 1918 р. в «Апокаліпсисі нашого часу», де йшлося про «Залізну Завісу», що опускається «над російською історією». Через два роки англійська публіцистка Е. Сноуден у книзі про Росію назвала ії «країною за Залізною Завісою».

У 1945 р. міністр пропаганди фашистської Німеччини Геббельс використав цю метафору для залякування населення європейських країн, на територію яких вступали радянські війська. В 1946 р. під час виступу в м. Фултоні (США) цим терміном скористався В. Черчилль, висловлюючи занепокоєння експансіоністською політикою СРСР, включенням деяких центрально i південносхідних країн Європи до радянської «сфери впливу». Термін «Залізна завіса»набув поширення і використовувався фактично до розпаду СРСР у 1991 р. [7, с. 265].

Ще однією концепцією національних інтересів у контексті зовнішньої політики держав можна визначити політику «нових кордонів» у США. Ця стратегія включала в себе проведення реформ у всіх основних сферах життя, зокрема, в освіті та охороні здоров'я; вирішення таких гострих проблем, як безробіття, житлове питання, расова дискримінація; розширення космічної програми [7, с. 32].

Наступною концепцією національних інтересів у контексті зовнішньої політики держав називаємо стратегію «блискучої ізоляції». «Блискуча ізоляція» - це термін, яким позначається загальний курс зовнішньої політики Англії другої половини XIX ст., що виражався у відмові від висновку тривалих міжнародних союзів. Острівне положення, величезні колоніальні володіння, сильний військовий флот, а головне - промислова й фінансова перевага над іншими державами дозволяли Англії зберігати свободу дій на міжнародній арені. Використовуючи протиріччя між європейськими державами, Англія прагнула до розширення і зміцнення свого міжнародного впливу. Політика «блискучої ізоляції» не заважала Англії укладати тимчасові угоди, що сприяли здійсненню iii експансіоністських цілей. 3 настанням епохи імперіалізму, у зв'язку зі швидким розвитком економіки й посиленням військової потужності інших держав, позиції Англії стали більш уразливі. Різке загострення стосунків з Німеччиною й іншими європейськими державами загрожувало Англії вимушеною ізоляцією. У 1902 р. Англія уклала тривалий союз з Японією, направлений проти Росії, а в 1904 р. - угода з Францією, що означало кінець політики «блискучої ізоляції» [3; 10, с.131].

Таке явище в міжнародній політиці як «Холодна війна» також можна розглянути в якості концепції національних інтересів. "Холодна війна» - глобальна геополітична, економічна та ідеологічна конфронтація між Радянським Союзом і його союзниками, 3 одного боку, та США, країнами Західної Європи і їх союзниками - 3 іншого, що тривала $з$ середини 1940-х до початку 1990-х років, призвела до розпаду СРСР та переросла в сучасне протистояння між Росією та Заходом.

Вперше термін «Холодна війна» застосував для опису протистояння Сполучених Штатів і Радянського Союзу Дж. Оруелл в статті «Ви і атомна бомба», що з'явилася на світ у 1945 р. Уперше публічно означеним цей термін був кастильським принцом X. Мануелем у XIV ст. Він зазначав, що «гарячі» і «холодні» війни відрізняються тим, як вони закінчуються. «Гарячі війни» закінчуються загибеллю держав або миром, а «холодні війни» не приносять ні миру, ні честі, тим, хто їх розв'язав.

На думку Т. В. Орлової, «холодна війна» стала третьою і останньою в XX ст. світовою війною. 3 одного боку, вона мала ознаки справжньої світової війни, яка закінчилася перерозподілом світу на користь переможців і повним крахом держав, що програли. Однак, з іншого боку, це була незвичайна, нетрадиційна війна, яка здійснювалася переважно в ідеологічній, політичній, 
економічній і технологічній сферах із використанням безпрецедентно жорстких невійськових i нетрадиційних засобів. Застосування цих засобів значною мірою визначило характер, форми i масштаб глобального протиборства, які, так само, як і наслідки протистояння, далеко не в усьому вписувалися у параметри «звичайної» світової війни.

Головними рушійними чинниками політики обох наддержав у другій половині 40-x-80-х pp. були взаємний страх і занепокоєння власною безпекою. Таким чином, головна ознака «Холодної війни» - це конфронтація в світовій політиці. Іншими ознаками були: ревізія узгоджених під час Другої світової війни рішень; формування військово-політичних блоків навколо двох великих держав; перегони озброєнь, в тому числі ракетно-ядерних; воєнно-силове мислення в зовнішній політиці; формування «образу ворога» засобами масової інформації. Оскільки обидві сторони уникали відкритого конфлікту, «холодна війна» велася в царині міжнародної політики та ідеології, економічного змагання, політичних і військових загроз, розвідки та підривної діяльності [1, С. 48-55; 4].

Останнім часом активізувалися дискусії навколо поняття гібридної війни. Певні дослідники стверджують, що будь-яка війна за своєю суттю є гібридною, бо поєднує в собі різні механізми ведення воєнних дій. Інші сучасні вчені наголошують на тому, що гібридні війни - це окремий специфічний вид війни. Так, гібридна війна - війна, основним інструментом якої $є$ створення державою-агресором в державі, обраній для агресії, внутрішніх протиріч та конфліктів з подальшим їх використанням для досягнення політичних цілей агресії, які звичайно досягаються звичайною війною.

Термін «гібридна війна» 3'явився ще у 2005 р. й став застосовуватися для опису стратегії Хезболли в Ліванській війні 2006 р. 3 того часу термін «гібридна»є домінуючим при обговоренні сучасних і майбутніх воєнних дій до такого ступеня, що вище військове керівництво взяло його на озброєння і використовує як основу сучасних воєнних стратегій.

Суть дискусії полягає в тому, що сучасні супротивники використовують звичайні/незвичайні, регулярні/нерегулярні, відверті/приховані засоби і застосовують усі виміри війни для подолання західної переваги в звичайній війні. Гібридні загрози передбачають застосування «всього спектра» сучасної війни, вони не обмежуються лише звичайними засобами.

Експерти називають гібридну війну типом конфлікту, який все частіше буде застосовуватися у ХІХ столітті [8].

Гібридна війна поєднує принципово різні типи і способи ведення війни, які скоординовано застосовуються задля досягнення основних цілей. Типовими компонентами гібридної війни $\epsilon$ використання методів, що сприяють виникненню та поглибленню в державі, обраній для агресії, внутрішніх конфліктів: війну;

- створення внутрішніх суспільних протиріч через пропаганду з іiї переходом у інформаційну

- створення економічних проблем через економічне протистояння з переходом в економічну війну та протидію зв'язкам країни-жертви з сусідніми країнами;

- підтримка сепаратизму та тероризму аж до актів державного тероризму;

- сприяння створенню нерегулярних збройних формувань (повстанців, партизан та ін.) та їх оснащення.

При цьому сторона-агресор намагається та може залишатися публічно непричетною до розв'язаного конфлікту.

Якщо ці методи війни виявляються дієвими, держава-агресор може досягти своїх агресивних цілей та закріпити успіх, виступили в ролі миротворця у внутрішньому конфлікті. У випадку, якщо ці методи виявляються мало дієвими, агресор може застосувати:

інші методи ведення війни з залученням у конфлікт на своєму боці третіх країн;

класичні прийоми ведення війни з прихованим локальним обмеженим застосуванням власних збройних сил або через неприховану агресію [9, с. 98].

Таким чином, у роботі проаналізовані сучасні концепції національних інтересів у контексті зовнішньої політики держав. Ці концепції демонструють силовий аспект, що домінує в теорії національних інтересів і в XX, і в XXI століттях, тобто й зараз переважає реалістичний підхід у політиці. XXI століття закономірно демонструє перевагу інформаційних технологій у захисті, реалізації та демонстрації національних інтересів. Важко визначити, яка саме концепція була більш дієвою та ефективнішою, бо та чи інша концепція має різні політичні, воєнні й економічні боки, а також різні цілі. Напевно, «політика нових кордонів» поєднує в собі всі елементи, 
необхідні для гармонійного розвитку держави. Тематика роботи торкається дискусійної проблеми, тому що проаналізовані концепції не всі дослідники вважають саме концепціями національних інтересів, відносять їх виключно до стратегій зовнішньої політики окремих держав. Але, беручи до уваги, що концепцію національних інтересів розглядаємо як систему можливої реалізації національних інтересів конкретної держави в певний проміжок часу, то стратегії, що означені в даному дослідженні, можна аналізувати як стратегії захисту й реалізації цінностей і потреб конкретних держави та суспільства, тобто національних інтересів. Перспективою подальших досліджень може бути аналітика концепцій національної безпеки різних держав, а також удосконалення концепції національних інтересів та стратегій зовнішньої політики України.

\section{Бібліографічний список:}

1. Бжезинський 3. «Холодна війна» та їі наслідки / Збігнєв Бжезинський // Політика і час. - 1993. № 1. - C. 48-55.

2. Вишневська І. Г. Категоріально-понятійний апарат стратегії стримування та залучення в американсько-китайських відносинах / І. Г. Вишневська // Актуальні проблеми міжнародних відносин (частина I). - 2014. - Вип. 120. - С. $151-161$.

3. Грубінко А. Роль Великої Британії у процесах європейської політичної інтеграції у повоєнний період (1945 - 1956 рр.) / Андрій Грубінко // Європейські історичні студії [Електронний ресурс]. - Режим доступу до ст. : http://eustudies.history.knu.ua/andrij-grubinko-rol-velykoyi-brytaniyi-u-protsesah-yevropejskoyipolitychnoyi-integratsiyi-u-povoyennyj-period-1945-1956-rr/

4. Історія міжнародних відносин (1914 - 2015) : [навч. посіб. для студентів ВНЗ, викл.] / [Я. Б. Турчин, Р. Б. Демчишак, Л. С. Матлай ; М-во освіти і науки України, Нац. ун-т «Львів. політехніка»]. - Львів : Вид-во Львів. політехніки, 2016. - 140 с.

5. Кэрбуне Р. Концепция национального интереса в теории международных отношений / Р. Кэрбуне [Электронный ресурс]. - Режим доступа к ст. : https://radjcarbune.wordpress.com/2015/09/03

6. Новітня історія країн Західної Свропи та Північної Америки (1918-1945рр.) : [посібник]

/ [3. А. Баран, Г. М. Кипаренко, С. П. Мовчан, М. М. Швагуляк]. - Львів : Афіша, 2008. - 288 с.

7. Політична енциклопедія / [Редкол. : Ю. Левенець (голова), Ю. Шаповал (заст. голови) та ін.] К. : Парламентське видавництво, 2011. - $761 \mathrm{c.}$

8. Пуйвелде ван Д. Гібридна війна - чи вона взагалі існує? / Дем’єн ван Пуйвелде // НатоРевю. Інформаційний вісник [Електронний ресурс]. - Режим доступу до ст. : https://www.nato.int/docu/review/ 2015/Also-in-2015/hybrid-modern-future-warfare-russia-ukraine/UK/index.htm

9. Требін М. П. Війна «гібридна» / Михайло Петрович Требін // Політологічний енциклопедичний словник / [Уклад. : Л. Герасіна, В. Погрібна та ін. ; за ред. проф. М. П. Требіна]. - Х. : «Право», 2015. C. 98.

10. Українська дипломатична енциклопедія : У 2-х т. / [Редкол. : Л. В. Губерський (голова) та ін.] К. : Знання України, 2004. Т. 1 - 760 с.

11. Українська дипломатична енциклопедія: У 2-х т. / [Редкол. : Л. В. Губерський (голова) та ін]. К. : Знання України, 2004. Т. 2 - 812 с.

12. Rosamond B. Theories of European Integration / B. Rosamond. - New York : St. Martin's Press, 2000.$278 \mathrm{p}$.

\section{Litvin L. A. The modern national interests concepts in the foreign policy of states context}

The aim of the paper is to analyze contemporary concepts of national interests in the context of foreign policy of states. It is noted that the national interests determine the strategy and tactics of the states' foreign policy, the nature of international relations and the features of domestic policy. It is noted that the practical realization of national interests should precede the theoretical substantiation of different concepts. Moreover, the study and analysis of existing concepts of national interests is a prerequisite for the creation of a new own concept that will respond to the effective development of the state, international and domestic conditions.

The features of such concepts as «rapid reaction strategy», the concept of «mutually guaranteed destruction», "oriental politics», «iron curtain», the doctrine of «mass retaliation», the program of «new borders», the policy of «instantaneous isolation», the doctrine of «intimidation», «Cold war», «hybrid war» are defined. The historical context and characteristics of the events concerning the realization of the concepts of national interests by the world states are indicated. The peculiarities of international relations in these periods are determined. Attention is drawn to the scientific discussion about the modern concept of «hybrid war», the main components of the "hybrid war» are named. It is noted that "the policy of new borders» combines all the elements necessary for the harmonious development of the state. 
It is specified that the analyzed concepts demonstrate a power aspect dominates in the theory of national interests both in the 20th and 21st centuries. It is noted that the realistic approach in politics prevails in the present days, and about the advantage of information technologies in defending, implementing and demonstrating national interests in the XXI century.

It is also specified that the subject of the article touches on the discussion problem, because the analyzed concepts are not considered by all researchers as concepts of national interests, referring them exclusively to foreign policy strategies of individual states. It is noted that the concept of national interests is considered as a system of possible realization of the national interests of a particular state within a certain period of time.

Key words: national interests, foreign policy, state, strategy. 